\title{
PENGGUNAAN MATA UANG VIRTUAL (BITCOIN) DALAM TRANSAKSI PASAR MODAL BERDASARKAN UU NO.7 TAHUN 2011 TENTANG MATA UANG DIHUBUNGKAN DENGAN UU.8 TAHUN 1995 TENTANG PASAR MODAL
}

\author{
oleh: \\ Yoga Nugraha Pratama \\ Meima
}

\begin{abstract}
ABSTRAK
Uang merupakan alat tukar menukar yang sangat mudah dibawa kemana-mana dan tahan awet. Uang diciptakan untuk mempermudah masyarakat atau manusia dalam jual beli dimanapun berada dan kapanpun berada, karena itu kita harus mempergunakan uang dengan sebaik-baiknya. Pada tanggal 2 November 1949 merupakan hari ditetapkan uang menjadi mata uang resmi negara Indonesia yang diatur dalam Undang-Undang No 7 Tahun 2011 Tentang Mata Uang. Seiring berkembangnya jaman mata uangpun berkembang dan saat ini yang muncul adalah mata uang virtual (Bitcoin), pengertian bitcoin adalah sebuah mata uang virtual yang pertama kali dikembangkan pada tahun 2009, oleh Satoshi Nakatomo, (nama samaran), Pada tahun 2017 Pemerintah Indonesia berencana untuk melegalkan mata uang virtual didalam kegiatan transaksi di pasar modal untuk mengikuti perkembangan jaman dan meningkatkan ekonomi di Indonesia menurut Undang-Undang No 8 Tahun 1995 Tentang Pasar Modal adalah kegiatan yang bersangkutan dengan Penawaran Umum dan perdagangan Efek, Perusahaan Publik yang berkaitan dengan Efek yang diterbitkannya, serta lembaga dan profesi yang berkaitan dengan Efek, dalam hal ini identfikasi masalah dari pernyataan diatas adalah bagaimanakan legalitas mata uang virtual (bitcoin) dalam transaksi pasar modal menurut hukum di Indonesia dan bagaimanakah penggunaan mata uang virtual (bitcoin) dalam pasar modal dikaitkan dengan Undang-Undang Nomor 8 Tahun 1995 Tentang Pasar Modal. Hasil penelitian menyimpulkan bahwa Penerapan pengaturan mengenai legalitas untuk menggunakan Bitcoin sebagai mata uang di Indonesia sangatlah sulit karena dalam Undang Undang Nomor 7 Tahun 2011 Tentang Mata Uang sudah sangat jelas bahwa mata uang yang sah $\mathrm{d}$ Indonesia adalah rupiah, terlebih BI menyatakan larangan tentang penggunaan Mata Uang Bitcoin dan Bitcoin juga bukan merupakan mata uang atau alat pembayaran yang sah di Indonesia. Penggunaan mata uang Bitcoin di pasar modal akan sangat terkendala karena PT Bitcoin Indonesia harus menyerahkan semua kewenangan dan pengaturan mata uang Bitcoin kepada Otoritas Jasa Keuangan sebagai lembaga pengawas pasar modal dan PT Bitcoin Indonesia juga harus menjadi Bank Kustodian karena Bank Kustodian adalah lembaga penyimpanan dan penyelesaian, perusahaan efek, atau bank umum yang telah mendapat persetujuan Bapepam.
\end{abstract}

\section{PENDAHULUAN}

\section{Latar Belakang}

Uang merupakan alat tukar menukar yang sangat mudah dibawa kemana-mana dan tahan awet. Uang diciptakan untuk mempermudah masyarakat atau manusia dalam jual beli dimanapun berada dan kapanpun berada, karena itu kita harus mempergunakan uang dengan sebaik-baiknya. Pada tanggal 2 November 1949 merupakan hari ditetapkan uang menjadi mata uang resmi negara Indonesia dan mata uang rupiah dicetak serta diatur oleh Bank 
Indonesia walaupun Kepulauan Riau dan Irian Barat memiliki variasi rupiah mereka sendiri tetapi penggunaan mereka dibubarkan pada tahun 1964 di Riau dan 1974 di Irian Barat. ${ }^{1)}$

Pengertian mata uang menurut ketentuan Pasal 1 ayat (1) Undang-Undang Nomor 7 Tahun 2011 tentang Mata Uang:

"Mata uang adalah uang yang dikeluarkan oleh Negara Kesatuan Republik Indonesia yang selanjutnya disebut Rupiah."

Seiring berkembangnya jaman mata uangpun berkembang dan saat ini yang muncul adalah mata uang virtual (Bitcoin), pengertian bitcoin adalah sebuah mata uang virtual yang pertama kali dikembangkan pada tahun 2009, oleh Satoshi Nakatomo, (nama samaran). Mata uang digital berfungsi sebagai uang Rupiah, Dollar, Euro, atau yang lainnya. Namun mata uang digital ini hanya tersedia di dunia digital saja. ${ }^{2)}$

Pada tahun 2017 Pemerintah Indonesia berencana untuk melegalkan mata uang virtual didalam kegiatan transaksi di pasar modal untuk mengikuti perkembangan jaman dan meningkatkan ekonomi di Indonesia. Pengertian pasar modal itu sendiri merupakan merupakan satu lembaga yang memobilisasi dana masyarakat dengan menyediakan sarana atau tempat untuk mempertemukan penjual dan pembeli dana-dana jangka panjang yang disebut Efek. Di Indonesia, perkembangan pasar modal berjalan secara fantastis atau dinamik. ${ }^{3)}$

Undang-Undang Nomor 8 Tahun 1995 tentang Pasar Modal memberikan pengertian tentang Pasar Modal yaitu kegiatan yang bersangkutan dengan Penawaran Umum dan perdagangan Efek, Perusahaan Publik yang berkaitan dengan Efek yang diterbitkannya, serta lembaga dan profesi yang berkaitan dengan Efek.

Menurut Pasal 1 ayat(5) Undang-Undang Nomor 8 Tahun 1995 tentang Pasar Modal, yang dimaksud dengan Efek adalah surat berharga, yaitu surat pengakuan utang, surat berharga komersial, saham, obligasi, tanda bukti utang, Unit Penyertaan kontrak investasi kolektif, kontrak berjangka atas Efek, dan setiap derivatif dari Efek. Efek atau surat berharga yang diterbitkan dan diperdagangkan di pasar modal Indonesia saat ini antara lain:4)

Saham (stock)

1. Saham preferen (preferred stock)

2. Obligasi (bond)

3. Obligasi konversi (convertibl bond)

4. Right (right)

5. Waran (warrant)

Saham (common stock) merupakan salah satu jenis efek yang paling banyak diperdagangkan di pasar modal. Ada dua jenis saham yaitu saham atas nama dan saham atas unjuk. Untuk saham atas nama, nama pemilik saham tertera diatas saham tersebut, sedangkan saham atas unjuk nama pemilik saham tertera nama pemilik saham tertera diatas saham. ${ }^{5)}$

Saham diperjualbelikan melalui sarana pasar modal di Indonesia disebut Bursa Efek. Bursa tersebut tidak membeli atau menjual saham-saham yang ada, melainkan bursa

${ }^{1}$ http://emina666 .blogspot. co.id/ $2015 / 06 /$ makalah- tentang -mata- uang-indonesia. html?m=1 diakses pada tanggal 16 maret 2018

${ }^{2}$ Edukasibitcoin.com diakses 16 maret 2018

${ }^{3}$ Najib A.Gisymar, Insider Trading dalam Transaksi Efek, cetakan pertama, Citra Aditya Bakti, Bandung, 1999, hlm. 9.

${ }^{4}$ Tjiptono Darmadji dan Hendy M.Fakhruddin, Pasar Modal di Indonesia: Pendekatan Tanya Jawab, edisi pertama, Salemba Empat, Jakarta, 200 1, hlm. 5.

${ }^{5}$ Pandji Anoraga dan Piji Pakarti Pengantar Pasal Modal PT Rineka Cipta, Semarang 2001, hlm 58. 
hanya merupakan tempat atau sarana bagi para investor untuk bertransaksi di dalamnya. Bursa efek mempunyai fungsi dan peranan untuk memberikan jasa-jasa antara lain:6)

1. Menyediakan informasi pasar seperti fluktuasi harga, volume perdagangan, informasi penting terhadap emiten.

2. Membuat aturan main yang dikenal sebagai peraturan bursa (peraturan percatatan, keanggotaan dan perdagangan) dengan tujuan agar semua pelaku bursa dapat memperoleh kesempatan yang sama baik dalam memperoleh informasi maupun kesempatan berdagang.

3. Menyediakan fasilitas perdagangan efek untuk anggota bursa dan emiten.

4. Memberikan pelayanan kepada para anggotanya, perusahaan yang telah mencatatkan efeknya maupun kepada investor, baik secara individu maupun institusional.

Transaksi pasar modal di Indonesia ada perusahaan yang menjadi wadah dari perusahaan pialang atau para pelaku di pasar modal dalam bentuk Perseroan Terbatas (PT) perusahaan tersebut adalah PT Bursa Efek Indonesia, Bursa Efek Indonesia itu sendiri merupakan penggabungan dari dua perusahaan bursa yaitu PT Bursa Efek Jakarta (BEJ) dan PT Bursa Efek Surabaya (BES).

PT Bursa Efek Indonesia sebagai tempat berlangsungnya transaksi di pasar modal yang dinaungi Bapepam-LK (Lembaga Keuangan) akan melegalkan uang virtual untuk menjadi salah satu alat transaksi di pasar modal hal ini akan bertentangan dari UndangUndang No.7 Tahun 2011 tentang mata uang ditambah menurut bank Indonesia mata uang adalah segala sesuatu yang diterima secara umum sebagai alat pembayaran yang resmi dalam rangka memenuhi suatu kewajiban secara umum mempunyai tiga tujuan yang berbeda bergantung pada penggunaannya yaitu sebagai alat tukar untuk pembayaran diantara konsumen, sebagai satuan dasar untuk menilai daya beli atau nilai yang dibayarkan untuk memperoleh barang dan jasa, dan sebagai alat penyimpanan nilai untuk mengukur nilai ekonomis. ${ }^{7)}$

\section{Identifikasi Masalah}

1. Bagaimanakah legalitas mata uang virtual (Bitcoin) dalam transaksi pasar modal menurut hukum di Indonesia?

2. Bagaimanakah penggunaan mata uang virtual (Bitcoin) dalam pasar modal dikaitkan dengan Undang-Undang Nomor 8 Tahun 1995 Tentang Pasar Modal?

\section{TINJAUAN PUSTAKA}

\section{A. Transaksi mata uang virtual (Bitcoin)}

Berbicara mengenai Bitcoin, tentu Anda perlu mengetahui tentang sejarah singkat Bitcoin tersebut. Bitcoin merupakan sebuah virtual currency atau uang elektronik yang konon diciptakan oleh seorang atau sekelompok orang yang mengatas namakan Satoshi Nakamoto. Lalu mengapa disebut seorang atau sekelompok orang? Alasannya karena memang tidak diketahui bahwa Satoshi Nakamoto merupakan nama asli atau nama samaran, atau mewakili nama satu orang atau sekelompok orang tersebut.

Kemudian pada tahun 2008, Satoshi Nakamoto menerbitkan sebuah makalah berjudul "The Cryptography Mailing List" di metzdowd.com yang menggambarkan sebuah mata uang digital Bitcoin tersebut. Kemudian berlanjut pada tahun 2009, ia merilis sebuah perangkat

\footnotetext{
${ }^{6}$ Hulwati, Transaksi Saham di Pasar Modal Indonesia Prespektif Hukum Ekonomi Islam, UII Press, Yogyakarta, 2001, hlm. 28.

${ }^{7}$ http://bi.go.id/id/kamus.aspx?id=U diakses tanggal 16 maret 2018
} 
lunak Bitcoin pertama yang meluncurkan jaringan dan unit pertama dari mata uang Bitcoin. Namun tidak seperti mata uang pada umumnya, Bitcoin memang tidak tergantung dan mempercayai penerbit utama. Perlu diketahui bahwa Bitcoin menggunakan sebuah database yang akan didistribusikan dan bisa menyebar ke node-node dari sebuah jaringan yang disebut P2P peer To Peer ke jurnal transaksi, lalu menggunakan kriptografi untuk menyediakan fungsi-fungsi keamanan dasar. Fungsi tersebut digunakan untuk memastikan bahwa Bitcoin hanya dapat dihabiskan oleh orang yang memilikinya, atau bahkan tidak pernah boleh dilakukan lebih dari satu kali. Jika berbicara tentang desain dari Bitcoin tersebut, sebenarnya Bitcoin memperbolehkan kepemilikan tanpa identitas Anonymous. Sehingga sisi negative Bitcoin dapat dijadikan sebagai sarana pemindahan kekayaan atau lebih sering disebut dengan nama pencucian uang. Bitcoin-bitcoin tersebut nantinya dapat disimpan pada komputer atau laptop pribadi dalam sebuah format file Wallet. Bisa juga disimpan oleh sebuah servis wallet pihak ketiga. Namun terlepas dari semua itu, Bitcoin-bitcoin dapat dikirim melalui jaringan internet kepada siapapun yang mempunyai sebuah alamat Bitcoin.

Perlu diketahui juga bahwa Topologi peer-to-peer Bitcoin dan kurangnya administrasi tunggal bisa membuatnya tidak mungkin untuk dikuasai pihak otoritas, pemerintahan apapun, atau untuk memanipulasi nilai dari Bitcoin-bitcoin tersebut, bahkan menyebabkan inflasi dengan memproduksi lebih banyak Bitcoin. Jumlah total keseluruhan Bitcoin terbatas hanya mencapai 21 juta.

Sebenarnya tidak hanya Bitcoin saja yang ada saat ini, namun ada sekitar ratusan koin digital dengan Currency-nya sendiri-sendiri. Misalnya saja, coin digital lain yang sedang booming saat ini, seperti Litecoin, Ripple, BitSharesX, Nxt, Peercoin, Dogecoin, Namecoin, Darkcoin, dan masih banyak lainnya. Namun dari beberapa koin digital tersebut, banyak orang tertarik dengan Bitcoin karena harga nilai tukarnya saat ini mencapai kurang lebih 1 BTC. Satu Bitcoin sama dengan \$5000 Jika dirupiahkan sekitar 50 sampai 61 juta.

Untuk masalah legalitas, penggunaan Bitcoin berbeda-beda di setiap negara. Untuk di Indonesia sendiri, pihak BI (Bank Indonesia) menyatakan bahwa Bitcoin dan virtual currency lainnya bukan merupakan mata uang atau alat pembayaran yang sah di Indonesia. Masyarakat Indonesia dihimbau untuk berhati-hati terhadap Bitcoin dan virtual currency lainnya. Segala risiko terkait kepemilikan atau penggunaan Bitcoin ditanggung sendiri oleh pemilik atau pengguna Bitcoin dan virtual currency lainnya. ${ }^{8)}$

Bitcoin adalah mata uang virtual yang diciptakan pada tahun 2009 oleh seorang ahli komputer yang tidak dikenal dengan menggunakan alias Satoshi Nakamoto dan dirilis sebagai perangkat lunak open source. Mata uang elektronik yang saat ini didasari oleh teknologi yang paling baru dan mulai menjadi pilihan sebagai pengganti emas. Bitcoin juga disebut dengan mata uang digital terdesentralisasi pertama, karena sistem ini bekerja tanpa repositori sentral atau administrator tunggal. ${ }^{9)}$

Menurut Social Science Research Network (SSRN). Bahwa pengertian cryptocurrency adalah sesuatu yang meningkatkan minat akan uang, numismatik, teknologi, dan investasi. Tetapi pemahaman yang komprehensif tentang teori dan fondasi mereka masih kurang diinginkan di antara banyak praktisi dan pemangku kepentingan. Makalah ini mensintesis dan merangkum literatur tentang cryptocurrency dengan tujuan untuk pemahaman yang lebih umum tentang tatanan dan tujuannya.

Menurut Andy Greenberg bahwa cryptocurrency Bitcoin berbeda, sepenuhnya menggantikan mata uang yang didukung negara dengan versi digital dan lebih sulit dipalsukan. Memotong batas-batas internasional, dapat disimpan di hard drive, bukan di bank.

${ }^{8}$ https:// cryptonews. co.id /sejarah-singkat - bitcoin - dari - tahun - 2009- hingga-sekarang Diakses tanggal pada tanggal 23 Juli 2018

${ }^{9}$ https:// www. Gomarketing strategic. Com /2017/11/ pengertian-kelebihan-manfaat-bitcoin.html Diakses pada 23 Juli 2018 
Dan yang paling penting bagi banyak pengguna Bitcoin, bahwa kripto tidak tunduk pada keinginan inflasi dari pimpinan pusat (Federal Reserve) yang memutuskan untuk mencetak lebih banyak koin.

Menurut Patrick McDonnell, bahwa Bitcoin adalah "hibrida" dari forex dan emas yang terstruktur digunakan untuk berdagang seperti saham dengan perlindungan stop loss dan perintah objektif laba. Ini membantu melestarikan modal dan memastikan keuntungan melalui forex seperti volatilitas pasar. Cryptocurrency bitcoin seperti emas yang dipandang oleh beberapa orang sebagai penyimpanan kekayaan jangka panjang yang layak. Cryptocurrency bitcoin dsebut "Emas digital", karena aspek penambangan yang memberi imbalan penambang berupa virtual Bitcoin untuk memecahkan persamaan matematika terenkripsi sekaligus menjaga jaringan yang mendasari (blockchain). Secara teori, "Seperti emas karena persediaan semakin terbatas, permintaan akan meningkatkan nilai dari waktu ke waktu." Bitcoin memiliki batasan di tempat yang hanya memungkinkan tercetak maksimal 21 juta koin. ${ }^{10}$ )

\section{A. Pasar Modal Sebagai Sarana Investasi}

Pasar Modal/Capital Market/Stock Exchange/Stock Market/ dalam dalam pengertian klasik diartikan sebagai suatu bidang usaha perdagangan surat-surat berharga seperti saham, sertifikat saham, dan obligasi atau efek-efek pada umumnya. ${ }^{11)}$ Menurut Pasal 1 angka 13 Undang - Undang Nomor 08 Tahun 1995 tentang Pasar Modal (Lembaran Negara Tahun 1995 Nomor 64, Tambahan Lembaran Negara. Nomor 3587) pengertian pasar modal yang lebihspesifik, yaitu kegiatan yang bersangkutan dengan penawaran umum dan perdagangan efek, perusahaan publik yang berkaitan dengan efek yang diterbitkannya, serta lembaga dan profesi yang berkaitan dengan efek. Pengertian pasar modal sebagaimana pasar konvensional pada umumnya, merupakan tempat bertemunya penjual dan pembeli. Pasar (market) merupakan saran yang mempertemukan aktivitas pembeli dan penjual untuk seuatu komoditas atau jasa. Pengertian modal (capital) dapat dibedakan: ${ }^{12}$ )

a. Barang modal (capital goods) seperti tanah, bangunan, gedung,mesin.

b. Modal uang (fund) yang berupa financialassets.

Pengertian pasar modal menurut beberapa ahli sebagai berikut: ${ }^{13)}$

"Secara umum, pasar modal mempunyai peran penting bagi perkembangan ekonomi suatu Negara karena pasar modal berfungsi sebagai: ${ }^{14)}$

a. Sarana untuk menghimpun dana-dana masyarakat untuk disalurkan ke dalam kegiatan-kegiatanproduktif;

b. Sumber pembiayaan yang mudah, murah, cepat bagi dunia usaha dan pembangunannasional;

C. Mendorong terciptanya kesempatan berusaha dan sekaligus menciptakan kesempatan kerja dan juga mempertinggi efisiensi alokasi sumberproduksi;

d. Memeperkokoh mechanism financial market dalam menata system moneter, karena pasar modal; dapat menjadi saran open market operation sewaktu- waktu diperlukan oleh Bank Sentral dan Menekan tingginya bunga menuju suatu rate yang reasonable."

${ }^{10} \mathrm{https}: / /$ coinaset.com/pengertian-cryptocurrency-menurut-para-ahli/ Diakses pada tanggal 30 Juli 2018

${ }^{11}$ Najib A. Gisymar. Insider Trading dalam Transaksi Efek. Bandung : Citra Aditya Bakt, 1999, hlm 10. 2004, hlm 10

${ }^{12}$ M. Irsan Nasarudin dan Indra Surya. . Aspek Hukum Pasar Modal Indonesia. Jakarta : Prenada Media,

${ }^{13} \mathrm{http}: / /$ www.spengetahuan.com/2017/10/pengertian-pasar-modal-menurut-para-ahli.html diakses tanggal 16 maret 2018 .

${ }^{14}$ Tavinayati dan Yulia Qamariyanti. Hukum Pasar Modal di Indonesia. (Jakarta: Sinar Grafika, 2013), $\mathrm{h} \operatorname{lm} 7$. 
Reksa dana (mutual fund) adalah sertifikat yang menjelaskan bahwa pemiliknya menitipkan uang kepada pengelola reksa dana (manajer investasi) untuk digunakan sebagai modal berinvestasi. Melalui dana reksa ini nasihat investasi yang baik "jangan menaruh semua telur dalam satu keranjang" bisa dilaksanakan. Pada prinsipnya investasi pada reksa dana adalah melakukan investasi yang menyebar pada sejumlah alat investasi yang diperdagangkan di pasar modal dan pasar uang. ${ }^{15)}$

Secara sederhana saham dapat didefinisikan sebagai tanda penyertaan atau pemilikan seseorang atau badan dalam suatu perusahaan. ${ }^{16)}$ Wujud saham adalah selembar kertas yang menerangkan bahwa pemilik kertas tersebut adalah pemilik perusahaan yang menerbitkan kertas tersebut. Laba yang besar dari saham didistribusikan kepada pemegang saham sebagi dividen.

Saham preferen memberikan pilihan tertentu atas hak pembagian dividen. Ada pembeli saham preferen yang menghendaki penerimaan dividen yang besarnya tetap setiap tahun, ada pula yang menghendaki didahulukan dalam pembagian dividen, dan lain sebagainya.

Obligasi adalah surat berharga atau sertifikat yang berisi kontrak antara pemberi pinjaman dengan penerima pinjaman. ${ }^{17)}$ Surat obligasi adalah selembar kertas yang menyatakan bahwa pemilik kertas tersebut memberikan pinjaman kepada perusahaan yang menerbitkan obligasi. Pada dasarnya memiliki obligasi sama persis dengan memiliki deposito berjangka. Hanya saja obligasi dapatdiperdagangkan.

Waran adalah hak untuk membeli saham biasa pada waktu dan harga yang sudah ditentukan. Biasanya waran dijual bersamaan dengan surat berharga lainnya, misalnya obligasi atau saham. Penerbit waran harus memiliki saham yang nantinya dikonversi oleh pemegang waran. Namun setelah obligasi atau saham yang disertai waran memasuki pasar baik obligasi, saham maupun waran dapat diperdagangkan secara terpisah. Kalau pemodal ingin mendapatkan dividen, terlebih dahulu ia menggunakan waran untuk membeli saham Capital gain bisa didapat bila pemegang obligasi yang disertai waran menjualnya dengan harga yang lebih tinggi dari harga ketika memperolehnya. ${ }^{18)}$

Right issuemerupakan hak bagi pemodal membeli saham baru yang dikeluarkan emiten. Ini berbeda dengan saham bonus atau dividen saham, yang otomatis diterima oleh pemegang saham. Right issue dapat diperdagangkan. Biasanya harga saham hasil right issue lebih murah dari saham lama. Karena membeli right issue berarti membeli hak untuk membeli saham, maka kalau pemodal menggunakan haknya otomatis pemodal telah melakukan pembelian saham. Dengan demikian maka imbalan yangakandidapat oleh pembeli right issue adalah sama dengan membeli saham, yaitu dividen dan capital gain. ${ }^{19)}$

Go public merupakan penawaran saham atau obligasi kepada masyarakat umum untuk pertama kalinya. Pertama kali di sini berarti bahwa pihak penerbit pertama kalinya melakukan penjualan saham atau obligasi. Transaksi penawaran umum penjualan saham pertama kalinya terjadi pada pasar perdana (primary market).

Pasar perdana adalah penawaran saham dari perusahaan yang menerbitkan saham (emiten) kepada investor selama waktu yang ditetapkan oleh pihak yang menerbitkan sebelum saham tersebut diperdagangkan di pasar sekunder (Secondary Market).

15 Gunawan Widjaya dan Almira Prajna Ramaniya. Reksana Dana dan Peran Serta Tanggung Jawab Manajer Investasi dalam Pasar Modal. Seri Pengetahuan Pasar Modal (Jakarta: Prenada Media Group, 2006.), hlm7.

${ }^{16}$ Edilius dan Sudarsono. Kamu Ekonomi Uang dan Bank (Jakarta:Rineka Cipta, 2001), hlm 239.

${ }^{17}$ Dyah Ratih S. Saham dan Obligasi Ringkasan Teori dan Soal Jawab, Univ. (Yogyakarta :Atmajaya, 2002), hlm 82.

18 Yulsafni. Hukum Pasar Modal........hlm 39-40.

${ }^{19}$ Ibid., hlm. 35. 
Istilah Emiten dapat kita temukan pada Pasal 1 angka 6 UU no 8 tahun 1995, Emiten adalah Pihak yang melakukan Penawaran Umum. ${ }^{20}$ ) Emiten adalah Pihak yang melakukan penawaran umum efek, baik efek yang bersifat ekuitas (saham), efek yang bersifat hutang (obligasi), efek yang bersifat syariah (sukuk).

Pihak yang melakukan penawaran umum saham / (Go Publik, Initial PublikOffering/IPO) adalah perusahaan yang berbentuk Perseroan Terbatas (PT), karena modal PT direpresentasikan atau dalam bentuk saham, sedangkan pihak yang melakukan penawaran umum obligasi atau sukuk disebut Emiten obligasi/atau sukuk, dimana tidak hanya perusahaan berbentuk PT saja, tetapisetiap pihak dimungkinkan untuk dapat menerbitkan atau menjual obligasi atau sukuk di pasar modal Indonesia.

Perusahaan Publik adalah Perseroan yang sahamnya telah dimiliki sekurangkurangnya oleh 300 (tiga ratus) pemegang saham dan memiliki modal disetor sekurangkurangnya Rp3.000.000.000,00 (tiga miliar rupiah) atau suatu jumlah pemegang saham dan modal disetor yang ditetapkan dengan Peraturan Pemerintah. Sejak perusahaan melakukan penawaran saham perdana di berlangsung maka investor akan memilih perusahaan mana yang paling lucrative kedalam fortopolionya. ${ }^{21)}$

\section{PEMBAHASAN}

\section{Pelimpahan Pt Bursa Efek Indonesia Kepada Otoritas Jasa Keuangan Tentang Kelayakan Mata Uang Virtual (Bitcoin) Di Pasar Modal}

Bursa Efek Indonesia atau disingkat menjadi BEI merupakan salah satu lembaga di pasar modal yang terbentuk melalui penggabungan (merger) antara Bursa Efek Jakarta dan Bursa Efek Surabaya, sebelum merger Bursa Efek Jakarta yang beroperasi di Jakarta dikelola oleh BAPEPAM milik pemerintah, sedangkan Bursa Efek Surabaya yang beroperasi di Surabaya dikelola oleh PT Bursa Efek Surabaya milik swasta, dan bursa paralel dikelola oleh Persatuan Pedagang Uang dan Efek-efek (PPUE).

Bursa Efek Indonesia menyerahkan sepenuhnya kepada Otoritas Jasa Keuangan (OJK), apakah bitcoin bisa digunakan di pasar modal atau tidak.

Sebagaimana diketahui, pasar modal merupakan kegiatan yang berhubungan dengan penawaran umum dan perdagangan efek, perusahaan publik yang berkaitan dengan efek yang diterbitkannya, serta lembaga dan profesi yang berkaitan dengan efek.

Samsul sebagai Direktur Penilaian Perusahaan BEI menyatakan nanti tergantung kepada OJK, apakah nanti ke depannya kan kita juga tidak tahu, mekanisme bisa digunakan di bursa atau tempat lainnya, semua itu hanya OJK yang bisa memutuskan. Sebab, OJK yang mengatur semua industri keuangan yang ada di Indonesia dan bagaimana mekanisme mata uang ini, apakah mungkin digunakan di bursa atau tempat lainnya, lebih banyak kepada keputusan strategis OJK yang menentukan.

Sebelumnya, Kepala Eksekutif Pengawas Pasar Modal Otoritas Jasa Keuangan (OJK), Hoesen menyatakan, penggunaan bitcoin masih belum mendapat legal yang nyata di mata hukum dan penggunaan mata uang virtual (bitcoin) belum ada izin. Penggunaan Bitcoin ini belum kita atur, karena belum dilakukan secara terbuka dan belum adanya legal hukum, maka OJK berencana mengatur transaksi investasi bitcoin. Tujuannya, demi mencegah kasus penipuan investasi bodong.

Meski bakal mengatur, pihak OJK tidak menyebutkan secara gamblang, apakah investasi bitcoin akan dilarang atau diberi izin resmi di Indonesia, nanti akan diatur mengenai penggunaan bitcoin. Karena sebetulnya sudah ada regulasi mengenai investasi, terutama investasi bodong. Itupun ada Satuan Tugasnya.

\footnotetext{
${ }^{20}$ Hendy M. Fakhruddim. Go Public. (Jakarta : PT Elex Media Komputindo, 2008), hlm 12-14

${ }^{21}$ Ibid hlm 17.
} 
Adanya penggunaan bitcoin, OJK mengingatkan masyarakat dan pemilik modal, agar mengecek terlebih dahulu aspek hukum dan lainnya sebelum menggunaan mata uang bitcoin tersebut dan kepada masyarakat agar mengecek terlebih dahulu apakah ada dasar hukumnya atau tidak, kan kita punya website dan call center yang bisa dihubungi kalau ragu. Bitcoin bukan merupakan alat pembayaran yang sah di Indonesia, termasuk dalam hal produk investasi. Pasalnya, bisa berisiko bagi yang masuk ke bitcoin. ${ }^{22}$

\section{Penggunaan Mata Uang Virtual (Bitcoin) Dalam Pasar Modal Dikaitkan Dengan Undang-Undang Nomor 8 Tahun 1995 Tentang Pasar Modal}

Menurut analisis penulis pada kasus yang kedua tentang penggunaan mata uang Bitcoin pada transaksi pasar modal dapat berdampak besar bukan hanya untuk perkembangan di pasar modal saja tetapi akan berdampak besar juga terhadap perekonomian di Indonesia, dimana jika mata uang Bitcoin ini digunakan akan menjadi terobosan baru terhadap perekonomian dimana pasar modal akan mengikuti perkembangan zaman.

Dilihat dari Undang Undang Nomor 8 Tahun 1995 Tentang Pasar Modal, pengertian pasar modal adalah kegiatan yang bersangkutan dengan Penawaran Umum dan perdagangan Efek, Perusahaan Publik yang berkaitan dengan Efek yang diterbitkannya, serta lembaga dan profesi yang berkaitan dengan Efek.

Apabila Bitcoin dilegalkan di Indonesia maka PT Bitcoin Indonesia selaku pemegang kewenangan atas Bitcoin harus mendaftarkan atau menyerahkan semua pengaturan transaksi Bitcoin ke Bank Kustodian, karena menurut Undang Undang Nomor 8 tahun 1995 Tentang Pasar Modal memberi pengertian bahwa Bank Kustodian adalah pihak yang memberikan jasa penitipan Efek dan harta lain yang berkaitan dengan Efek serta jasa lain, termasuk menerima deviden, bunga, dan hak hak lain, menyelesaikan transaksi Efek, dan mewakili pemegang rekening yang menjadi nasabahnya. Dan dapat dilihat di Pasal 43 Undang Undang Nomor 8 Tahun 1995 Tentang Pasar Modal bahwa yang dapat menyelenggarakan kegiatan usaha sebagai kustodian adalah lembaga penyimpanan dan penyelesaian, perusahaan efek, atau bank umum yang telah mendapat persetujuan Bapepam, dan persyaratan dan tata cara pemberian persetujuan bagi bank umum sebagai kustodian diatur lebih lanjut dengan peraturan pemerintah.

Pasal 90 Undang Undang Nomor 8 Tahun 1995 Tentang Pasar Modal menyatakan bahwa, dalam kegiatan perdagangan Efek, setiap Pihak dilarang secara langsung atau tidak langsung:

1. Menipu atau mengelabui pihak lain dengan menggunakan sarana dan atau cara apapun

2. Tutut serta menipu atau mengelabui pihak lain, dan

3. Membuat pernyataan tidak benar mengenai fakta yang material atau tidak mengungkapkan fakta yang material agar pernyataan yang dibuat tidak menyesatkan mengenai kegiatan yang terjadi pada saat pernyataan dibuat dengan maksud untuk menguntungkan atau menghindarkan kerugian untuk diri sendiri atau pihak lain atau dengan tujuan mempengaruhi pihak lain untuk membeli atau menjual efek.

Berdasarkan pernyataan dari Pasal 90 diatas menegaskan bahwa apabila Pasar Modal ingin menggunakan Bitcoin dalam transaksinya maka PT Bitcoin Indonesia harus segara mendaftaran keabsahan Bitcoin ke Otoritas Jasa Keuangan sebagai badan pengawas pasar modal, jika tidak maka PT Bitcoin Indonesia melanggar apa yang di uraikan pada Pasal 90 diatas dan akan diberikan sanksi administrasi sebagaimana tertera pada Pasal 102 Undang Undang Nomor 8 Tahun 1995 Tentang Pasar Modal:

${ }^{22}$ http://www.tribunnews.com/bisnis/2017/12/14/bei-limpahkan-sepenuhnya-ke-ojk-soal-kelayakaninvestasi-bitcoin-di-pasar-modal Diakses pada tanggal 3 Agustus 2018 
1. Bapepam mengenakan sanksi administrative atas pelanggaran Undang Undang ini dan atau peraturan pelaksanaannya yang dilakukan oleh setiap pihak yang memperoleh izin, persetujuan, atau pendaftaran dari Bapepam.

2. Saksi administratif sebagaimana dimaksud dalam ayat (1) dapat berupa:

3. Peringatan tertulis

4. Denda yaitu kewajiban untuk membayar sejumlah uang tertentu

5. Pembatasan kegiatan usaha

6. Pembekuan kegiatan usaha

7. Pencabutan izin usaha

8. Pembatalan persetujuan, dan

9. Pembatalan pendaftaran

10. Ketentuan lebih lanjut mengenai sanksi administratif sebagaimana dimaksud dalam ayat (1) dan ayat (2) ditetapkan dengan peraturan pemerintah

Bitcoin akan sangat sulit untuk digunakan dalam transaksi di Pasar Modal sebab dari penukarannya pun Bitcoin belum jelas dan nilai tukar Bitcoin juga relatif tidak stabil, memang ada dampak positif dan negatif dari penggunaan mata uang Bitcoin ini, dampak positif dan negatif penggunaan Bitcoin ini sebagai berikut: Kelebihan untuk Bitcoin adalah biaya transfer yang sangat kecil. Untuk melakukan pengiriman uang, Bitcoin tidak memotong biaya yang besar. Untuk sekali transfer, berapapun nilai yang dikirimkan potongan yang dikenakan hanya Rp 500 hingga $\mathrm{Rp} 3.000$ dan dapat diakses dimanapun dari perangkat elektronik yang bisa koneksi dengan internet seperti Handphone, laptop dan lain lain.

Kekurangan untuk Bitcoin adalah nilai tukar Bitcoin yang fluktuatif atau tidak stabil, dan Bitcoin ini rawan sebagai pencucian uang dari hasil kejahatan, serta cara penukaran yang belum familiar bagi masyarakat yang ingin menggunakan mata uang Bitcoin ini.

Berdasarkan pernyataan diatas, penulis dapat menyimpulkan bahwa penggunaan Bitcoin di dalam transaksi pasar modal sangat sulit untuk direalisasikan terlebih banyak tahapan yang harus dilakukan pemerintah khususnya Otoritas Jasa Keuangan untuk mengkaji lebih lanjut mengenai penggunaan Bitcoin ini, penggunaan Bitcoin memang mempunyai banyak dampak positif tetapi Bitcoin juga mempunyai banyak dampak negatif dan ini beberapa kelebihan dan kelemahan Bitcoin:

1. Kelebihan Bitcoin

a. Bitcoin beredar dalam jaringan komputer dunia, sehingga kita bisa mengirim dan menerima kiriman uang dimanapun dan kapanpun. Anda tak perlu khawatir transfer uang berjeda libur nasional atau sejenisnya seperti yang dialami jika transfer dana via bank.

b. Penyimpanan Bitcoin bebas biaya. Kalaupun akan ada charge dari penyedia Wallet Bitcoin, maka mereka harus mendapatkan persetujuan Anda dulu sebelum memotong dana dalam simpanan Anda.

C. Pembayaran dalam Bitcoin sepenuhnya terjadi dalam enkripsi/kriptografi, sehingga info pribadi aman dan tak bisa dilihat orang lain. Yang bisa dilihat orang lain hanya alamat yang digunakan untuk transfer saja. Anda pun jadi terlindungi dari kasus pencurian identitas yang marak di perbankan biasa.

d. Protokol Bitcoin tidak bisa dikontrol oleh siapapun, baik perorangan, lembaga, maupun pemerintah dan terlebih Bitcoin juga mempunyai sistem keamanan yang di sebut rantai blok, Rantai yang paling utama (hitam) terdiri dari seri terpanjang yang berasal dari dari blok awal (hijau) dari blok yang sekarang. Blok yang tidak berpemilik (abu - abu) ada di luar rantai utama.

Transaksi apapun yang di siarkan ke node - node lainnya tidak secara langsung menjadi resmi sampai diakui dalam sebuah daftar-waktu yang telah dicap dari 
semua transaksi yang diketahui, yaitu disebut sebagai rantai blok. Pengakuan ini berasal dari sebuah sistem yang diyakini jalan untuk mencegah pengeluaran ganda dan pemalsuan.

Saat-saat tertentu, setiap node yang menghasilkan mengoleksi semua transaksi transaksi tidak diakui yang mana diketahui dari dalam sebuah blok kandidat, sebuah file yang mana di antara lainnya, mengandung hash kritografi dari blok-yang berlaku sebelumnya dan diketahui pula oleh node tersebut. Kemudian node itu mencoba untuk menghasilkan sebuah hash kriptografi dari blok itu dengan karakteristik tertentu, sebuah usaha yang membutuhkan sebuah nilai yang dapat diprediksi dari pengulangan percobaan dan kesalahan. Ketika sebuah node menemukan sebuah solusi, dia akan mengumumkannya ke semua jaringan. Anggota jaringan akan menerima blok baru yang telah di pecahkan dan mengvalidasikannya sebelum menerima, dan kemudian menambahkannya ke rantai. Akhirnya, rantai blok mengandung sejarah kriptografi kepemilikan dari semua koin - koin yang berasal dari alamat sang pembuat ke pemilik alamat yang sekarang. Oleh karena itu, kalau seorang pengguna berusaha untuk mengunnakan kembali koin - koin yang telah dia belanjakan, maka jaringan akan menolak transaksi tersebut.

e. Biaya transaksi sangat rendah atau bahkan nol. Bahkan meski Anda melakukan penukaran Bitcoin ke mata uang biasa di Exchange atau Marketplace, biayanya masih lebih rendah ketimbang transfer bank, Kartu Kredit, maupun PayPal.

\section{Kelemahan Bitcoin}

a. Masih banyak orang belum mengenal Bitcoin maupun sistem mata uang digital.

b. Jika dibandingkan dengan bisnis yang menerima mata uang biasa, maka bisnis/perusahaan yang menerima Bitcoin itu jumlahnya masih sangat sedikit. Dan kadang-kadang, meski suatu perusahaan mau menerima pembayaran dengan Bitcoin, tetapi Customer Service tidak paham, sehingga menimbulkan ketidaknyamanan dalam bertransaksi.

c. Volatilitas harga harian Bitcoin sangat tinggi, sehingga sering terjadi kenaikan dan penurunan harga secara drastis.

d. Bitcoin masih dalam pengembangan, sehingga fitur-fiturnya pun masih sangat terbatas.

e. Tidak ada jaminan regulasi pemerintah manapun di dunia. Bahkan Bank Indonesia yang mengatur peredaran uang di nusantara pun menyatakan secara implisit bahwa Bitcoin bukanlah alat pembayaran resmi, dan Anda menanggung sendiri risiko jika tetap ingin menggunakannya.

\section{PENUTUP}

\section{Kesimpulan}

Penerapan pengaturan mengenai legalitas untuk menggunakan Bitcoin sebagai mata uang di Indonesia sangatlah sulit karena dalam Undang Undang Nomor 7 Tahun 2011 Tentang Mata Uang sudah sangat jelas bahwa mata uang yang sah d Indonesia adalah rupiah, terlebih BI menyatakan larangan tentang penggunaan Mata Uang Bitcoin dan Bitcoin juga bukan merupakan mata uang atau alat pembayaran yang sah di Indonesia. Atas dasar itu, masyarakat perlu untuk berhati-hati dengan maraknya transaksi bitcoin di Indonesia. Terlebih lagi, penggunaan transaksi bitcoin terbilang mudah lantaran melalui dunia maya dan dapat diakses dari perangkat elektronik yang bisa terhubung dengan koneksi internet.

Penggunaan mata uang Bitcoin di pasar modal akan sangat terkendala karena PT Bitcoin Indonesia harus menyerahkan semua kewenangan dan pengaturan mata uang Bitcoin 
kepada Otoritas Jasa Keuangan sebagai lembaga pengawas pasar modal dan PT Bitcoin Indonesia juga harus menjadi Bank Kustodian karena Bank Kustodian adalah lembaga penyimpanan dan penyelesaian, perusahaan efek, atau bank umum yang telah mendapat persetujuan Bapepam, dan untuk menjadi Bank Kustodian bukan hal yang mudah terlebih mata uang Bitcoin harus melalui beberapa tahapan untuk mendapatkan legalitas penggunaannya di pasar modal, karena pemerintah khususnya Otoritas Jasa Keuangan harus mengkaji lebih lanjut mengenai penggunaan Bitcoin ini, penggunaan Bitcoin memang mempunyai banyak dampak positif tetapi Bitcoin juga mempunyai banyak dampak negatif.

\section{Saran}

Mengenai penggunaan mata uang Bitcoin di dalam transaksi pasar modal akan membuat transaksi di pasar modal lebih mudah dan efisien karena nilai tukar bitcoin yang cukup besar terhadap rupiah, otoritas Jasa Keuangan harus segera memutuskan apakah pasar modal dapat digunakan dalam pasar modal atau tidak karena apabila ditunda dikhawatirkan akan terjadi pelanggaran di dalam transaksi pasar modal tersebut.

\section{DAFTAR PUSTAKA}

Dyah Ratih S. Saham dan Obligasi Ringkasan Teori dan Soal Jawab, Univ. (Yogyakarta :Atmajaya, 2002

Edilius dan Sudarsono. Kamu Ekonomi Uang dan Bank Jakarta:Rineka Cipta, 2001

Gunawan Widjaya dan Almira Prajna Ramaniya. Reksana Dana dan Peran Serta Tanggung Jawab Manajer Investasi dalam Pasar Modal. Seri Pengetahuan Pasar Modal (Jakarta: Prenada Media Group, 2006.

Hendy M. Fakhruddim. Go Public. (Jakarta : PT Elex Media Komputindo, 2008

Hulwati, Transaksi Saham di Pasar Modal Indonesia Prespektif Hukum Ekonomi Islam, UII Press, Yogyakarta, 2001

M. Irsan Nasarudin dan Indra Surya. . Aspek Hukum Pasar Modal Indonesia. Jakarta : Prenada Media, 2004

Najib A.Gisymar, Insider Trading dalam Transaksi Efek, cetakan pertama, Citra Aditya Bakti, Bandung, 1999

Pandji Anoraga dan Piji Pakarti Pengantar Pasal Modal PT Rineka Cipta, Semarang 2001

Tavinayati dan Yulia Qamariyanti. Hukum Pasar Modal di Indonesia. (Jakarta: Sinar Grafika, 2013),

Tjiptono Darmadji dan Hendy M.Fakhruddin, Pasar Modal di Indonesia: Pendekatan Tanya Jawab, edisi pertama, Salemba Empat, Jakarta, 200

http://emina666 blogspot. co.id/ 2015 /06/makalah- tentang -mata- uang-indonesia. html?m=1 diakses pada tanggal 16 maret 2018

Edukasibitcoin.com diakses 16 maret 2018

http://bi.go.id/id/kamus.aspx?id=U diakses tanggal 16 maret 2018

https:// cryptonews. co.id /sejarah-singkat - bitcoin - dari - tahun - 2009- hingga-sekarang Diakses tanggal pada tanggal 23 Juli 2018

https:// www. Gomarketing strategic. Com /2017/11/ pengertian-kelebihan-manfaatbitcoin.html Diakses pada 23 Juli 2018

https://coinaset.com/pengertian-cryptocurrency-menurut-para-ahli/ Diakses pada tanggal 30 Juli 2018

http://www.spengetahuan.com/2017/10/pengertian-pasar-modal-menurut-para-ahli.html diakses tanggal 16 maret 2018.

http://www.tribunnews.com/bisnis/2017/12/14/bei-limpahkan-sepenuhnya-ke-ojk-soalkelayakan-investasi-bitcoin-di-pasar-modal Diakses pada tanggal 3 Agustus 2018 